\title{
Et brev fra Bjørnson til Det medisinske fakultet
}

Julen 1887 sendte Bjørnstjerne

Bjørnson (1832-1910) et brev til Det medisinske fakultet i Kristiania. Han ønsket en klargjøring av fakultetets syn på kjønnslig avhold. Brevet var trolig et bidrag i sedelighetsfeiden, den store moraldebatten i 1880-årene rundt prostitusjon, seksualmoral og kvinnefrigjøring.

\section{Ragnar Stien}

ragnarstien@hotmail.com

Mogens Thorsensgt. 1

0264 Oslo

Utgangspunktet for sedelighetsfeiden var angrepene på den strenge, kristelige kjønnsmoral fra bohemdikterne, slike som Hans Jæger (1854-1910), Christian Krohg (1852-1925) og Gabriel Finne (1866-99), og ikke minst fra Bjørnstjerne Bjørnson (1832-1910). På mange vis starter debatten med hans skuespill En hanske (1887) hvor han krevde likestilling mellom kjønnene når det gjelder seksualmoral. Denne likestillingen ble angrepet fra kirkelig side, mens radikalerne og bohemene latterliggjorde Bjørnsons forsvar for seksuell avholdenhet før ekteskapet. I denne striden søkte Bjørnson, litt uventet, støtte fra medisinsk hold $\mathrm{i}$ argumentasjonen mot bohemene. I et brev datert 1. juledag 1887 skrev han (1):

\section{Til det medicinske fakultet ved Kristiania} universitet:

Der har varet norske loger - og kanske er der saadanne ennu - som $i$ visse tilfceller har givet celdre og yngre moen det råd at søke legemlig omgang. Selvfølgelig ligger det noer at tro, at heri har de havt (eller har) fakultetes medhold, og at dette gikk (eller går) ut fra, at legemlig omgang er en nødvendighed for moeneskets helse og velvoere. Jeg tror at gjøre saken og fakultetet en tjeneste ved at meddele dette, så vi kan få grei besked.

I cerbødighed

Bjørnstjerne Bjørnson
Brevet er vel ikke helt klart formulert, men må muligens ses i sammenheng med et annet brev som fakultetet fikk på omtrent samme tid. Dette brevet var datert 2. desember 1887 fra «Foreningen til Fremme av Sædelighed» og ber om fakultetets kommentarer til påstander som er fremmet i bohemlitteraturen (1):

1. Kjønslig Afholdenhed er skadelig for Manden som for Kvinden.

2. Kjønslig Afholdenhed fremkalder hos Manden Selvbesmittelse og Spermatorrhoe, derfor kan disse Sygdomme alene helbredes ved kjønslig Omgang.

3. Kjønslig Afholdenhed fremkalder hos Kvinden Blegsot og Hysteri, derfor kan disse Sygdomme ikke helbredes under fortsat kjønslig Afholdenhed.

4. Pligt ved præventive Midler at gjøre Samlivet ufrugtbart.

Professor i hygiene og farmakologi, Ernst Ferdinand Lochmann (1820-91), utferdiget et utkast til svar som sterkt støttet det kirkelige synet og helt forkastet bohemlitteraturens påstander i utvetydige ordelag (1).

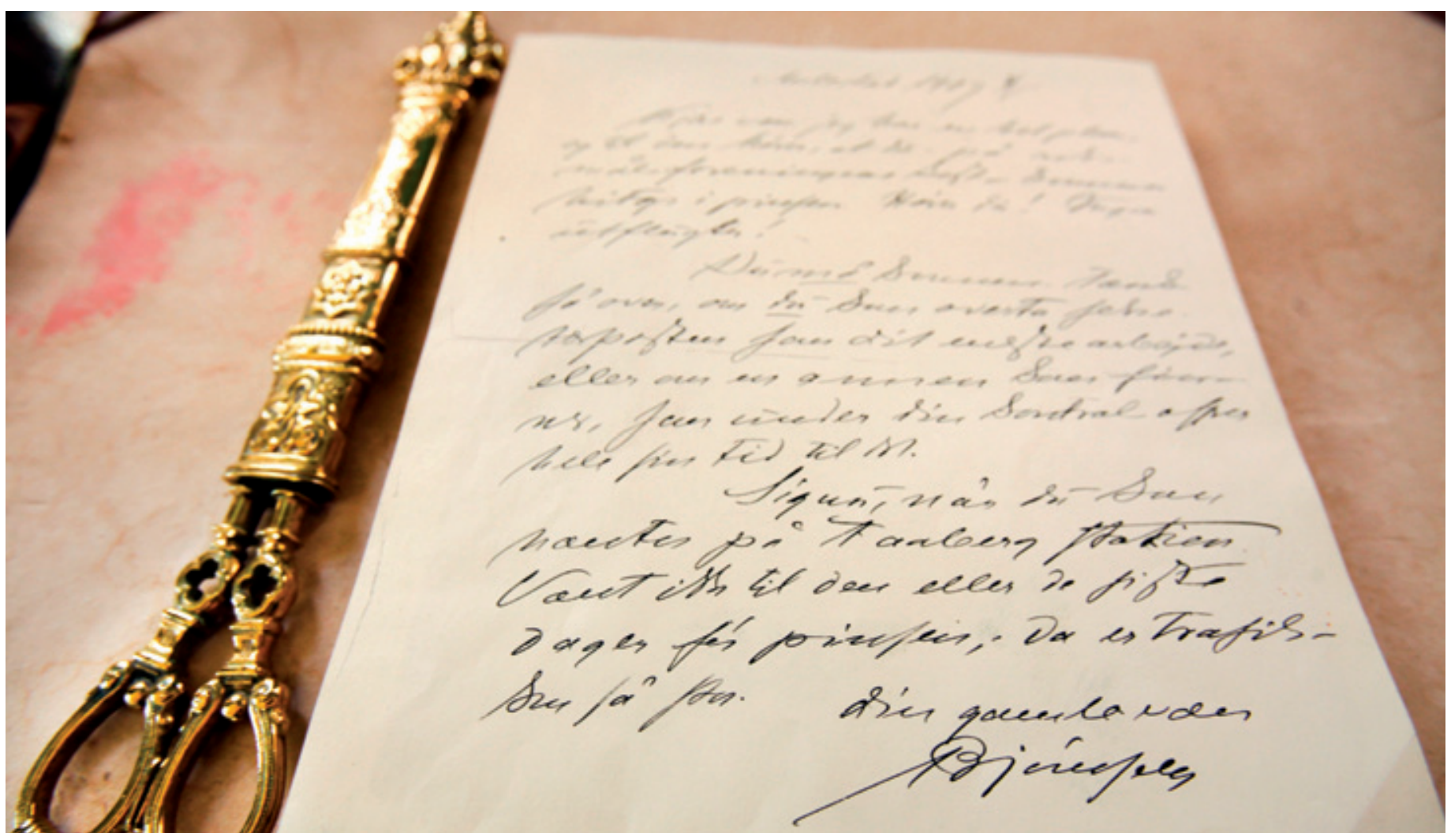
med brev fra Bjørnson, er det flere tusen brev som fortsatt ikke er utgitt. Illustrasjonsfoto av et brev forfattet av Bjørnstjerne Bjørnson. Foto SCANPIX 
Lochmann var kjent for sine meget konservative kristelige synspunkter i naturvitenskapelig sammenheng. Han drev en iherdig kampanje mot «darwinistiske standpunkter og benektinger» og hevdet at det ikke kunne reises tvil om «en skaberakt som forklaring af den første livsspires tilblivelse». Flere av de andre professorene reagerte på Lochmanns forslag, og det endelige svaret, som ikke foreligger i fakultetets arkiv, synes å være at «så langt fakultetets kjennskap til den medisinske litteratur angår, så er påstandene [fra bohemene] feil og at avholdelse i ungdommen snarere er en vei til sunnhet.» Svaret til Bjørnson foreligger heller ikke, men vi kan gå ut fra at innholdet er i overensstemmelse med de håndskrevne kommentarer (1) professorene utferdiget til svaret til Sedelighetsforeningen.

\section{Bjørnson og legene}

I Bjørnson-året, hundre år etter hans død, kan det være rimelig å påpeke støtten Bjørnson antakelig forventet fra legehold. Han hadde tidligere, i forarbeidene til Over cevne første stykke (1883) oppsøkt nevrologiprofessor Jean-Martin Charcots (1825-93) berømte åpne tirsdagsforelesninger ved Salpêtrière-hospitalet i Paris (hvor han bodde første del av 1880-årene). I den trykte utgaven av Over cevne henviser han på siste side til nettopp Charcot og hans elev Paul Richers (1849-1933) publikasjoner om epilepsi og hysteri (2). I På guds veje (1889) er også den rasjonelle hovedpersonen lege. Selv i En hanske er den modererende personen lege. Hans forhold til legestanden var likevel ikke alltid like velvillig. Tidsskriftet har tidligere redegjort for hans anmeldelse av en lege for feilbehandling - antakelig den første rettssak av denne type mot en lege i Norge (3). Bjørnsons død i Paris i 1910 skyldtes et opphold der for å bli «d'Arsonvalisert», en elektrisk behandling av senfølgene av hans apopleksi. Elektrisk behandling var nok gått av moten i Norge, og legene her ikke spesielt velvillige ovenfor herr d'Arsonval som de nok oppfattet som en kvakksalver $(4,5)$. Men
Bjørnson mente altså at norske legers bedømmelse av metoden ikke var overbevisende nok. Som i mange andre spørsmål, svingte nok også Bjørnsons oppfatning av legene betraktelig i løpet av hans arbeidsår.

Oppgitte interessekonflikter: Ingen

\section{Litteratur}

1. Det medisinske fakultets arkiv 1887. Riksarkivet.

2. Aarli JA. Over Evne I. I: Dietrichs E, Stien R, red. Hjernen og kunsten. Oslo: Nevrolitterære klubb, 2001: 39-42

3. Ranheim B. Bjørnstjerne Bjørnson, husmannskonen og legene. Tidsskr Nor Lægeforen 1997: 117 4399-402.

4. Aarli JA. Medisinsk behandling i utlandet. Hvorfor Bjørnstjerne Bjørnson døde i Paris 1910. Tidsskr Nor Lægeforen 1995; 115: 3740-4.

5. Aarli JA. A forgotten Nobel prize laureate: Death in Paris. I: Dietrichs E, Stien R, red. The brain and the arts. Oslo: Koloritt, 2008: 113-23.

Manuskriptet ble mottatt 7.4. 2010 og godkjent 9.11. 2010. Medisinsk redaktør Erlend Hem. 